\title{
BMJ Global Health Five years from now, who will be setting the global health agenda?
}

\author{
Anu Kumar
}

To cite: Kumar A. Five years from now, who will be setting the global health agenda? BMJ Global Health 2021;6:e008045. doi:10.1136/ bmjgh-2021-008045

Received 18 November 2021 Accepted 9 December 2021

Check for updates

C Author(s) (or their employer(s)) 2021. Re-use permitted under CC BY-NC. No commercial re-use. See rights and permissions. Published by BMJ.

Ipas, Chapel Hill, North Carolina USA

Correspondence to

Dr Anu Kumar;

kumara@ipas.org
Those of us based in the USA and Europe have been driving the global health agenda for too long. It is time for us to move over.

After nearly 50 years as a traditionally structured international non-governmental organization, Ipas is on a path to dramatically change the way we operate. We are an international reproductive justice organisation, with offices in 16 countries in Asia, Africa and the Americas, working to ensure that abortion and contraception are accessible to all. That mission will not change. But we are transforming from a traditional 'hub and spoke' organisation with power centred in the USA to a 'networked' organisation with authority, power and leadership dispersed and shared across the countries where we work.

\section{WHY THIS CHANGE OF COURSE?}

Power and equity are key. Since becoming president and chief executive officer of Ipas in 2018, these issues have been on my mind a lot-just as they have been on the minds of many in the global health and development fields. It is time to re-envision our strategies and reshape our organisations to become more just and equitable, and to centre our work closest to the people we serve.

As Seye Abimbola, Madhukar Pai and others have observed in the ongoing discussion about decolonising global health, decolonising is not simply a matter of adding new diversity, equity and inclusion programmes. "To transcend its origins, global health must become actively anti-supremacist, and also anti-oppressionist and anti-racist," Pai and Abimbola wrote in The Lancet. "The focus is not only on things that can be easily measured, but also on things that matter but cannot be easily counted-for example, how new voices are heard and prioritised and how the people who now make the field diverse go about reshaping it for the better." That is why the journey we are now on is about fundamentally changing the structure and operations of Ipas.

\section{WHERE WE ARE HEADING}

Ipas was founded in 1973 with staff and programming coming from the USA. In the mid-1990s, we began opening country offices and hired local staff to lead and work in those offices, a practice that continues today. Nonetheless, power has been primarily held in the USA, prompting a longstanding conversation within Ipas about decentralisation. In 2018, we began seriously considering what decentralisation would specifically mean for Ipas and concluded it not only would position us more strongly for the future and lead to more local leadership, but would also increase the impact of our work and our contribution to the global reproductive justice movement. Thus, it was not only the right thing to do, but it was also a smart thing to do.

We realised that we must move past the dichotomy of 'centre' and 'periphery' and reshape Ipas into a post-colonial organisation-a journey we are calling the Ipas Road Map, which launched in July 2020. At that time, we had recently embarked on a new strategic framework which more deeply rooted our work in local ecosystems. ${ }^{2}$ External change was rampant as well. Around the world, there was a wave of racial uprisings in the wake of the murder of George Floyd. Shifts in the donor landscape were making themselves felt as well. And all of this was happening against the backdrop of COVID19 , which was laying bare health, gender and economic inequities that we had been fighting before the pandemic.

That put us on the multiyear journey we are engaged in today. It is about:

- Shifting power across the organisation, rather than holding it in a central body.

- Redistributing resources-human and financial-toward the countries and people closest to our work.

- Fostering ownership and autonomy for all involved.

In addition, we are paying more attention to language as we go forward. We are 
removing geography from our thinking and speaking in neutral terms about the relationships within Ipas. For instance, while there will still be staff in the USA, the USA office will no longer be the 'headquarters' and 'country offices' will not exist in a dialectic relationship to a headquarters. Instead, all offices will be in a relationship with each other on the same level. With power dispersed and shared, all parts of the networked organisation will work together as peers in a flatter, horizontal relationship.

\section{HOW WE ARE DOING IT (THE PROCESS)}

The first phase of the Road Map was dedicated to envisioning the type of organisational structure that would best meet our goals. We established a working group with oversight of the Road Map process. Key decisions about the future of Ipas traditionally have been made by the Ipas leadership team based in the USA, but this new group broke that paradigm, representing leaders from Bangladesh, India, South Africa, Malawi, Nigeria, Mozambique, Mexico and Central America, in addition to the US-based executive team.

Early on, we adopted a shared leadership approach to management and created a working definition of shared leadership, which says in part: 'Shared leadership is an organizational philosophy affirmed by our core value of interdependence...[and] will continually move us towards shared responsibility and authority, strategic distribution of resources, and mutual accountability.'

The group also reviewed several possible organisational models, including federations and franchises, and felt that a network model is best suited for Ipas's strategic framework, our commitment to equity and our financial resources. While some parts of the network will operate as independent entities, all will remain united by brand, mission, shared leadership, financial integrity and core values. We interviewed numerous experts with insights on governance, organisational change, network design and shared leadership. They shared lessons learnt, both positive and negative, about the transformation of their organisations or groups familiar to them.

\section{INITIAL PROGRESS}

Power is very much about money. One of the most important ways we are living into shared leadership is by putting major funding decisions into the hands of a wider group of leaders. To date, decisions for allocating nearly $\$ 34$ million have been made by various committees representing the Ipas executive team, country directors and senior staff. We now ensure that a majority of the participants are in the countries where we work and not from Ipas USA. They are charged with developing criteria for making decisions on the specific allocations involved, and doing so in a transparent, inclusive and fair manner. They also share the criteria and decisions with all staff.

Power is also about people. In filling staff positions, we are taking geography out of the equation. 'Open to all Ipas staff, globally' is a phrase now seen regularly in job announcements internally. Applicants outside the USA are encouraged to apply for jobs that historically have been housed in the USA and can remain in the country where they currently live. This is creating change. For the first time, our global fundraising efforts are led by a director of development based outside the USA. Several other positions traditionally based in the USA, including the director of quality care, and some of our finance, human resources and communications staff, are also now based in other countries. And in January 2022, the chair of the Ipas Board of Directors will for the first time in Ipas's history be based in a country where we work outside of the USA.

Becoming a post-colonial organisation also requires us to fight structural and institutional racism. We are in the midst of an organisation-wide equity review to understand how staff experience policies, practices, and other structural and institutional systems at Ipas. Ipas USA has established an Anti-Racism and Equity Committee, a self-governed group led by staff volunteers. In the USA office, we embraced salary transparency and are working towards this organisation wide.

We are also beginning to see shared leadership take shape regionally and locally. We were inspired by Frederic Laloux's work on reinventing organisations, ${ }^{3}$ which lead our Ipas Central America and Mexico office to create a new leadership team representing a cross-section of staff with skills in areas including finance, health services, communications and advocacy. The new team meets weekly, with an open agenda to discuss issues big or small, with the goal of building a regional organisation with a common identity and direction.

The original Road Map oversight working group, meanwhile, has now handed the reins to a new group of staff and leaders. This group is also geographically diverserepresenting Ipas offices in Bangladesh, South Africa, Bolivia, Mozambique and the USA-and reaches deeper into the staff structure. Simultaneously, there are smaller implementation groups of technical experts working on everything from a monitoring, learning and evaluation plan for the organisational change to cost recovery.

\section{CHALLENGES/OPPORTUNITIES}

It is hard to undo old patterns and build new ones. We have had a vertical 'chain of command' for nearly 50 years and are now trying to develop a horizontal, more fluid leadership structure. It will take time, practice, mistakes and learning from those mistakes to build new skills.

Admittedly, there are lots of difficult questions involved. As country 'nodes' become more independent and locally registered, what will the accountability structure be? How do we ensure that we maintain technical and operational quality?

Those are the kinds of issues we are tackling now. We are developing agreements, both legal and value based, that will be signed by each part of the network and will cover such issues as conflict resolution, local governance 
and assurance that all parts of the network continue to work toward the Ipas mission of making abortion and contraceptive care available to all.

This will require a lot more time and thought. But the opportunities opened up by shifting power are well worth it. We believe that, among other benefits, it ultimately will bring about deeper cross-country collaboration, greater flexibility in programming, more avenues for fundraising, and new and diverse voices in the global movement for reproductive justice. But time will tell.

Ipas, like any other INGO, has a limited ability to change the architecture of the global health and development fields. We need donors and partners to come along with us on this power-shifting journey. We also need to keep sharing ideas, innovations and resources, and listening and lifting up those closest to the work we aim to do. This journey is about shifting power so that we can better deliver on our mission to ensure reproductive freedom and autonomy for all people, regardless of who they are or where they live.

Twitter Anu Kumar @AnuKumarlpas; Ipas @IpasOrg

Acknowledgements The author thanks Madhu Pai and Seye Abimbola for their encouragement, Margie Snider for editorial support, the leadership team at Ipas for doing much of the work described in the paper, and the staff of Ipas for embracing these changes.

Contributors AK conceived and contributed to the final manuscript.

Funding The authors have not declared a specific grant for this research from any funding agency in the public, commercial or not-for-profit sectors.

Competing interests None declared.

Patient consent for publication Not required.

Ethics approval This study does not involve human participants.

Provenance and peer review Not commissioned; internally peer reviewed.

Open access This is an open access article distributed in accordance with the Creative Commons Attribution Non Commercial (CC BY-NC 4.0) license, which permits others to distribute, remix, adapt, build upon this work non-commercially, and license their derivative works on different terms, provided the original work is properly cited, appropriate credit is given, any changes made indicated, and the use is non-commercial. See: http://creativecommons.org/licenses/by-nc/4.0/.

\section{REFERENCES}

1 Abimbola S, Pai M. Will global health survive its decolonisation? Lancet 2020;396:1627-8.

2 Ipas strategic framework. Available: https://www.ipas.org/about-us/ strategy/ [Accessed 03 Dec 2021].

3 Thinkers 50 Frederic Laloux. Available: https://thinkers50.com/ biographies/frederic-laloux/ [Accessed 03 Dec 2021]. 